\title{
PERGESERAN PERILAKU WAMA-WAMA (STUDI ATAS PARA PENCARI SEDEKAH DI KECAMATAN BONANG DEMAK)
}

\author{
Muhamad Mustaqim a,1,* \\ ${ }^{a}$ Institut Agama Islam Negeri Kudus, 59311, Indonesia \\ ${ }^{1}$ muhamadmustaqim@stainkudus.ac.id *
}

Article history:

Received : 2019-07-22

Revised : 2019-10-30

Accepted : 2020-06-01

\section{Keywors:}

Behavior

Alms Seekers

Beg

Kata kunci:

Perilaku

Pencari Sedekah

Mengemis

This study attempted to investigate the behavior of charity seekers in several villages in Bonang Demak sub-district. This study tried to compare the study that the author conducted seven years before, with wider object and focus of research. The study used a sociological and anthropological approach. The findings revealed that there was a shift in alms seeker behavior mode. First, the letter or proposal model has not been used anymore, although sporadically some still use this model. Second, the model of selling calendars was a model widely used, since it was more elegant. There were products sold like businesses, and minimize the prejudice of fraud as already existed. The model of selling calendars was actually the use of new packages of old content, namely exploiting religion for economic purposes. The implication was that the community did not need to hesitate if they did not want to give / to buy alms to the citizens.

\section{ABSTRAK}

Tulisan ini mengkaji tentang perilaku para pencari sedekah (wamawama) di beberapa desa di kecamatan Bonang Demak. Penelitian ini mencoba membandingkan kajian yang pernah penulis lakukan tujuh tahun sebelumnya, dengan beberapa perluasan obyek dan fokus penelitian. Metode yang digunakan dalam penelitian ini lebih menggunakan pendekatan sosiologis dan antropologis. Hasilnya, ada pergeseran modus perilaku pencari sedekah. Pertama, model surat atau proposal sudah mulai tidak digunakan, meskipun secara sporadis beberapa masih menggunakan model ini. Kedua, model menjual kalender menjadi model yang banyak digunakan, karena lebih elegan, ada produk yang dijual seperti bisnis, dan meminimalisasi adanya prasangka penipuan yang selama ini ada. Model menjual kalender sebenarnya merupakan penggunaan bungkus baru dari isi lama, yakni bagaimana menggunakan agama untuk kepentingan ekonomi. Implikasinya, masyarakat tidak perlu sungkan apabila tidak memberi/membeli sedekah kepada para wama-wama.

\section{Pendahuluan}

Fenomena pengemis memang menjadi fenomena menarik di negeri ini. Di samping menjadi penghalang "keindahan" tata kota, yang hal ini biasanya terkaitan dengan pemerintahan daerah dan Satpol PP, fenomena mengemis juga menjadi semacam ideologi kemiskinan. Beberapa daerah bahkan ada yang menginisiasi Peraturan Daerah (Perda) yang melarang memberikan sesuatu kepada pengemis, misalnya di Bandung (www.pojokjabar.com, 2017), Depok (www.depok.go.id, 2013) dan 
beberapa daerah lainnya. Jika ada seseorang yang memberi uang kepada pengemis, maka yang bisa dipidana bukan pengemisnya, namun malah pemberinya. Alur berfikirnya, jika semua orang tidak berempati terhadap pengemis, maka secara perlahan kegiatan mengemis akan hilang. Mengemis, tidak lagi menjadi indikator sebuah kemiskinan, beberapa bukti menunjukkan bahwa secara ekonomi, para pengemis ini relatif kaya.

Melihat fenomena "pengemis kaya" tersebut, kita seakan terhenyak protes, hanya dengan kerja menadahkan tangan bisa mendapatkan uang banyak, terkadang ada yang seharian kerja hanya bisa dapat uang yang relatif kecil, bahkan di bawah standar upah minimum kabupaten. Di sinilah kiranya, fenomena pengemis menjadi kompleks, tidak hanya dalam tinjauan ekonomi, namun juga sosiologis, bahkan teologis.

Studi yang pernah penulis dan tim lakukan pada tahun 2011 tentang "Tradisi Mengemis: Pergulatan antara Ekonomi dan Agama"(Saleh, Riyanto, \& Mustaqim, 2014) kiranya semakin memperkuat hipotesis ini. Penelitian tentang para pencari sedekah di daerah pesisir salah satu kabupaten di Jawa Tengah - menunjukkan bahwa kegiatan meminta sedekah, dengan dalih meminta sumbangan untuk pembangunan lembaga keagamaan, sebagian besar dilatar belakangi oleh faktor ekonomi. Cara kerjanya, mereka membawa proposal pembangun masjid atau pesantren, dengan mendatangi rumah door to door, hasil dari sumbangan tersebut sebagian besar masuk ke kantong mereka, meskipun ada "jatah" yang diberikan kepada panitia pembangunan.

Kajian yang dilakukan oleh Juliardi dan Yatim yang melakukan penelusuran terhadap jaringan pengemis anak perempuan menunjukan bahwa faktor ekonomi (terpaksa untuk memenuhi kebutuhan hidup) menjadi salah satu motivasi praktik mengemis. Hanya saja pada kasus di Bukitinggi ini, ada relasi jaringan yang menopang praktik ini. Misalnya ada jaringan dengan pola hubungan sosial vertikal, dengan pihak-pihak "kekuasaan", seperti preman, ketua ormas sebagai backing mereka (Yatim \& Juliardi, 2016).
Keberhasilan perilaku mengemis, sebenarnya sebagian besar didukung oleh sikap pemurah masyarakat kita. Karakter filantropi, simpati, mudah kasihan yang dimiliki oleh masyarakat kita, barang kali menjadi modal utama bagi maraknya praktik mengemis ini. Dan memang, budaya dan nilai sosial kita sangat permisif terhadap sikap dermawan tersebut. Apalagi kalau para pengemis itu mengalami kekurangan secara "fisik", siapa yang tidak tersayat sanubarinya untuk tidak bersimpati? Ajaran agama juga memerintahkan untuk saling menolong dan menyayangi, khususnya dengan para fakir miskin. Dalil bahwa "tangan di atas itu lebih baik dari pada tangan di bawah" lebih banyak digunakan oleh para pemberi, jarang sekali dibaca oleh para pelaku praktik mengemis.

Mengemis dalam budaya kemiskinan, tidak sekedar mengais rejeki untuk bertahan hidup. Lebih dari itu, mengemis merupakan profesi yang mampu digunakan untuk akumulasi kekayaan. Budaya yang permisif terhadap perilaku ini akan selalu langgeng, terwariskan dari generasi ke generasi (Supraptingsih, 2012). Dalam kasus tertentu, kemiskinan bahkan bisa dikomodifikasi. Beberapa kasus, banyak para gelandangan dan pengemis yang dikoordinir oleh seorang "boss". Mereka harus menyetor sejumlah uang, supaya profesi mengemisnya itu aman dan nyaman. Bahkan ketika mereka terjaring razia, sang boss akan dengan mudah mengatasinya. Dalam relasi ini, tentu saja sang boss dan jaringannya memperoleh pendapatan yang lebih besar. Inilah pola kerja komodifikasi mengemis.

Secara sosiologis, perilaku mengemis ini terjadi karena beberapa faktor yang sebenarnya cukup kompleks, seperti faktor ekonomi, agama, budaya dan juga faktor sosial. Faktor-faktor tersebut tidak bisa ditentukan mana yang paling dominan secara general, diperlukan riset dan kajian yang mendalam untuk mampu menelisik faktor tersebut. Setiap kasus memiliki corak yang berbeda. Misalnya faktor agama, dalam penelitian yang sebelumnya pernah dilakukan di Dukuh Asinan Demak, faktor agama merupakan salah satu faktor yang juga memberi andil dari perilaku meminta sedekah yang dilakukan oleh wama-wama. Penelitian ini sebenarnya adalah kelanjutan 
dari penelitian sebelumnya, dengan memperluas fokus kajian di beberapa daerah yang memilki kesamaan dalam penyebutan istilah wama-wama ini. Selain itu memperluas cakupan pada perilaku keagamaan, akan lebih mampu memahai secara komprehensif beberapa singgungan dalam perilaku wama-wama ini.

\section{Tinjauan Pustaka}

\section{a. Terminologi Mengemis}

Tidak mudah untuk menyelami sejarah akar kata pengemis secara pasti. Sehingga terminologi tentang pengemis ini memunculkan beberapa pendapat. Salah satu pendapat mengatakan bahwa istilah pengemis berasal dari bahasa Jawa, hal ini mengingat istilah ini terdapat dalam kamus-kamus bahasa Jawa. Namun dalam kamus jawa kuno semacam Old Javanese-English Dictionary (Zoetmulder, 1982) atau versi terjemahannya dalam bahasa Indonesia (1995) istilah ini tidak ditemukan. Dalam Kamus Besar Bahasa Indonesia (1991 dan 2001), kata mengemis punya dua arti, yakni "meminta-minta sedekah," dan "meminta dengan merendah-rendah dan dengan penuh harapan." Sedang pengemis adalah orang yang meminta-minta. Menurut kamus ini, kata dasar mengemis adalah emis dan bukan Kemis (Saiful Umam, 2010).

Dalam Kamus Besar Bahasa Indonesia (Kamus besar bahasa Indonesia, 2017) dan Kamus Umum Bahasa Indonesia (Badudu \& Zain, 1994) penjelasan terhadap kata mengemis juga kurang lebih sama dengan yang ada dalam KBBI di atas, begitu juga kata dasarnya, emis. Sementara itu, Bausastra Jawa-Indonesia (Praiwiroatmodjo, 1981) dan Kamus Jawa-Indonesia (Purwadi, 2003) menjelaskan bahwa kata dasar ngemis adalah emis yang mempunyai arti meminta-minta. Kata Kemis, menurut dua kamus bahasa Jawa tersebut, hanya berarti hari dan tidak disebut sama sekali bahwa kata dasar dari ngemis.

Penjelasan yang sedikit berbeda terdapat dalam Kamus Umum Bahasa Indonesia (Poerwadarminta, 1984). Di satu sisi disebutkan bahwa mengemis, yang berarti meminta sedekah atau meminta-minta, berasal dari kata dasar emis. Tetapi, di sisi lain, pembaca juga diminta melihat kata Kemis. Dalam penjelasan kata Kemis, selain berarti hari kelima, juga merupakan kata dasar dari berkemis, mengemis dan pengemis. Arti mengemis dan pengemis dari kata dasar Kemis ini sama persis dengan yang berasal dari kata emis. Informasi ini sedikit berbeda dengan kamus-kamus yang disebutkan di atas yang sama sekali tidak menyinggung kemungkinan bahwa mengemis berasal dari Kemis.

Penjelasan yang sedikit lebih tegas terdapat dalam Practish JavaanschNederlandsch Woordenboek, sebagaimana di kutip oleh Umam (Saiful Umam, 2010). Disebutkan bahwa kata dasar ngemis adalah Kemis yang mempunyai dua arti, yakni "meminta-minta pada Kamis petang yang dilakukan oleh santri," dan "meminta-minta dalam pengertian umum." Pada perkembangan selanjutnya, istilah mengemis kemudian lumrah digunakan untuk semua perilaku meminta-minta yang dilakukan seseorang. Perilaku ini biasanya dilakukan di tempat atau lokasi umum yang banyak dikunjungi orang, selain juga secara personal berkunjung ke rumah-rumah. Tempat keramaian, khususnya lokasi ziarah (Walisongo) dan lampu lalu lintas, menjadi lokasi yang sering kali dijadikan tempat mangkal oleh para pengemis ini.

Penelitian yang dilakukan oleh Supraptiningsih (Supraptiningsih, 2016) menjelaskan bahwa pengemis adalah orang yang mendapatkan penghasilan dengan cara meminta-minta di muka umum dengan berbagai cara dan alasan untuk mengharapkan belas kasihan dari orang lain. Dan jika ini dilakukan untuk memenuhi kebutuhan hidup maka ini disebut dengan mata pencaharian atau pekerjaan.

\section{b. Pencari Sedekah: Singgungan antara Budaya, Ekonomi dan Agama}

Penelitian yang dilakukan oleh Humaidy dengan judul "Pergeseran Budaya Pengemis di Masyarakat Desa Pragaan Daya Sumenep Madura" mengupas secara tajam budaya mengemis masyarakat Desa Pragaan Daya Sumenep Madura (M. Ali Humaidy, 2003). Hasil penelitian menunjukkan ada pergeseran budaya, dari modus yang konvensional atau tradisional kepada praktek mengemis yang non-konvensional atau professional. Dalam 
penelitian ini juga dibahas latar belakang munculnya mengemis, internalisasi nilai, modus operandi dan konstruksi sosialnya.

Beberapa literatur yang berkaitan dengan tema penelitian ini adalah buku "Islam Pesisir" (Syam, 2005). Buku ini memberi gambaran tentang fenomena keberagamaan masyarakat pesisir di Jawa Timur. Dalam buku ini diungkap beberapa gejala-gejala keberagamaan masyarakat pesisir pantai dengan berbagai karakteristiknya. Buku ini memberi referensi pustaka pada penelitian ini untuk mengcover pola keberagamaan masyarakat pesisir. Meskipun mempunyai objek penelitian yang berbeda, tetapi karakteristik Islam dan pesisir setidaknya menjadi titik temu fenomena sosial keagamaan yang dikaji.

Untuk kajian tentang pengemis, pustaka yang digunakan adalah dua buku karya Suparlan. Buku pertama berjudul "Gelandangan Pandangan Ilmu Sosial" (Suparlan, 1986). Meskipun merupakan terbitan lama, buku ini masih relevan untuk mengkaji fenomena gelandangan dan pengemis. Dalam buku ini dipaparkan gambaran tentang fenomena gelandangan, dilihat dari berbagai aspek. Relevansi bagi penelitian ini adalah sebagai kerangka untuk mendeskripsikan fenomena pengemis, mulai dari kemunculan, dampak dan pergeseran budaya yang terjadi. Sehingga mampu membantu menganalisis fenomena pengemis terorganisir dalam masyarakat yang diteliti.

Buku berjudul "Kemiskinan di perkotaan” (Suparlan, 1983) membidik tentang gejala kemiskinan dan dampaknya dalam pembentukan prilaku secara psikis. Menurut analisis Parsudi, kemiskinan bukanlah semata-mata berupa kekurangan dalam ukuran ekonomi, tetapi juga melibatkan kekurangan dalam ukuran-ukuran kebudayaan dan kejiwaan (psikologi) dan memberikan corak tersendiri pada kebudayaan yang ada serta diwariskan dari suatu generasi ke generasi berikutnya sehingga terciptalah "budaya kemiskinan".

Penelitian yang pernah penulis lakukan bersama tim pada tahun 2011 tentang "Tradisi Mengemis: Pergulatan antara Ekonomi dan Agama" (Saleh dkk., 2014) menjadi dasar dan bahan kajian pendahuluan penelitian ini. Penelitian tentang para pencari sedekah di daerah pesisir salah satu kabupaten di Jawa Tengah - menunjukkan bahwa kegiatan meminta sedekah, dengan dalih meminta sumbangan untuk pembangunan lembaga keagamaan, sebagian besar dilatar belakangi oleh faktor ekonomi.

Cara kerjanya, mereka membawa proposal pembangun masjid atau pesantren, dengan mendatangi rumah door to door, hasil dari sumbangan tersebut sebagian besar masuk ke kantong mereka, meskipun ada "jatah" yang diberikan kepada panitia pembangunan. Perbedaan dengan penelitian kali ini adalah terletak pada fokus kajian dan lingkup objek penelitian. Jika sebelumnya penelitian fokus pada motivasi dan modus yang dilakukan oleh para wama-wama, maka pada penelitian ini akan lebih mengkaji pada perilaku wama-wama dalam berbagai aspek. Selain itu, jika sebelumnya fokus penelitian hanya terbatas pada satu dusun saja, maka fokus penelitian pada penelitian ini lebih luas yang meliputi beberapa desa di kecamatan yang sama.

Penelitian tentang pengemis yang dilakukan oleh Juliardi dan Yatim tentang kajian terhadap jaringan pengemis anak perempuan juga akan mampu memberi perbandingan realitas segaligus membantu menganalisis tentang fenomena para pencari sedekah. Penelitian tersebut menunjukan bahwa faktor ekonomi, yang menurut penulis dikatakan karena terpaksa untuk memenuhi kebutuhan hidup, menjadi salah satu motivasi praktik mengemis. Hanya saja pada kasus di Bukittinggi ini, ada relasi jaringan yang menopang praktik ini. Misalnya ada jaringan dengan pola hubungan sosial vertikal, dengan pihak-pihak kekuasaan", seperti preman, ketua ormas sebagai backing atau yang melindungi mereka (Yatim \& Juliardi, 2016).

Sementara Supraptingsih dalam kajianya menyatakan bahwa tradisi mengemis lebih karena faktor budaya yang mengitarinya (Supraptingsih, 2012), (Supraptiningsih, 2016). Senada, riset Hardiyantina menegaskan bahwa yang menjadi motif utama bagi masyarakat untuk melakukan pekerjaan mengemis adalah perilaku "mengemis" yang turun temurun sehingga membentuk sebuah entitas budaya lokal. Selain itu, kualitas sumber daya manusia juga masih rendah yang dapat 
mengakibatkan pola pikir masyarakatnya kurang kreatif dan memandang hidup secara sempit (Hardiyantina \& Sukardi, 2016).

Dalam kajian yang dilakukan oleh Damayanti dkk, beberapa faktor yang mempengaruhi perilaku pengemis atau peminta sedekah di antaranya adalah faktor sosial, seperti tingkat pendidikan yang rendah, faktor ekonomi seperti kurangnya pekerjaan formal, dan faktor budaya meliputi keterbatasan fisik dan keturunan. Lebih lanjut, jika dilihat dari kerangka teori sosial dramaturgi, maka ada panggung depan dan panggung belakang bagi para pencari sedekah ini. Kondisi sosial ekonomi pengemis panggung depan yaitu para pengemis menunjukkan diri sebagai orang miskin sehingga terlihat layak untuk dikasihani dan diberi sumbangan. Panggung belakang menghasilkan temuan berupa tingkat memperoleh pendapatan yang tinggi. Pengemis sudah memiliki tempat tinggal dengan kondisi bangunan fisik yang baik (Damayanti, Arsal, \& Sulaha, 2016).

\section{Metodologi Penelitian}

Penelitian ini termasuk dalam jenis penelitian lapangan, dengan menggunakan pendekatan kualitatif. Penelitian dilaksanakan pada bulan Mei-November 2018 dengan mengambil tempat atau fokus penelitian di tiga desa di Kecamatan Bonang, yaitu Desa Kembangan, Desa Krajanbogo dan Desa Tlogoboyo. Ketiga desa dipilih karena sebaran wama-wama banyak ditemukan di ketiga desa tersebut. Meskipun tidak menutup kemungkinan desa-desa sekitar yang berkaitan dengan objek penelitian akan menjadi bagian dari lokasi penelitian dalam penelitian ini. Tempattempat lain yang terkait dengan tema penelitian juga menjadi fokus penelitian ini, misalnya lokasi praktik wama-wama dalam melaksanakan aktifitas mencari sedekah, yang bisa dilakukan di mana saja.

Pendekatan kualitatif berlandaskan pada filsafat postpositivisme, digunakan untuk meneliti pada kondisi objek yang alamiah, dimana peneliti adalah sebagai instrumen kunci, teknik pengumpulan berupa triangulasi (gabungan), analisis data bersifat induktif, dan hasil penelitian lebih menekankan makna daripada generalisasi (Sugiyono, 2008, hlm. 15).

Pendekatan kualitatif selalu berusaha memahami pemaknaan individu (subjective meaning) dari subjek yang ditelitinya. Karena itu, peneliti melakukan interaksi atau komunikasi yang intensif dengan pihak yang diteliti, termasuk di dalamnya peneliti harus mampu memahami dan mengembangkan kategori-kategori, pola-pola dan analisa terhadap proses-proses sosial yang terjadi di tengah masyarakat yang diteliti (Creswell, 1994, hlm. 157). Hal ini dimungkinkan mengingat subjek kajian dalam penelitian ini merupakan sesuatu yang terkadang dianggap "tabu" oleh masyarakat, sehingga beberapa informan terkadang tidak bersedia menjelaskan secara terbuka, tidak mau menunjukkan identitas dan ada rasa curiga serta takut kepada peneliti. Berbagai simbol, atribut, komunikasi non verbal dalam hal ini sangat mendukung dalam penggalian data dalam penelitian ini. Pendekatan sosiologis dan antropologis dalam hal ini digunakan dalam rangka mengumpulkan, memahami, dan menyimpulkan berbagai data yang didapatkan dalam penelitian.

\section{Hasil dan Diskusi}

Seiring berjalannya waktu, ada proses di mana wama-wama ini mengalami dinamisasi. Beberapa orang menyatakan "keluar" dari profesi wama-wama tersebut. Sebagian yang lain masih meneruskan, bahkan mewariskannya kepada keluarganya. Berdasarkan pada penelitian yang pernah penulis lakukan pada tahun 2011 ada beberapa pergeseran perilaku wama-wama ini. Berikut akan dipaparkan pergeseran tersebut, baik pada sisi sosial, modus maupun pola keagamaan.

\section{Beberapa praktik wama-wama mulai berkurang.}

Di beberapa komunitas, profesi wamawama ini sudah mulai ditinggalkan. Beberapa faktor, mulai dari kesadaran adanya rasa malu, sudah mendapatkan pekerjaan lain, sampai pada keterbatasan fisik menjadi alasan mereka keluar dari profesi ini. Salah seorang mantan wama-wama bernama Sariyem (bukan nama sebenarnya) misalnya, yang tidak melakukan praktik wama-wama ini karena faktor usia. Menurutnya dia sudah 
tidak kuat lagi harus melakukan perjalanan ke rumah-rumah yang kadang sampai sehari penuh. Informan lain, sebut saja Hidayah (bukan nama sebenarnya) yang meninggalkan praktik wama-wama ini karena sudah mendapat pekerjaan yang menurutnya sudah cukup layak.

Menurut penuturan Choliq, salah satu tokoh di Dukuh Asinan Desa Kembangan, aktifitas wama-wama saat ini sudah mulai berkurang. Mereka kebanyakan sudah meninggalkan praktik ini. Jikalau masih ada yang melakukan, itu hanyalah sedikit. Menurutnya, hanya beberapa keluarga di salah satu RT yang masih mempertahankan perilaku ini.

Hal ini tidak lepas dari upaya tokoh masyarakat untuk berupaya meminimalisasi perilaku wama-wama. Choliq mengatakan selama ini dirinya dan para tokoh lainnya sudah sering memperingatkan untuk tidak melakukan praktik wama-wama ini. Namun beberapa orang yang merasa "nyaman" dengan profesi ini tidak bergeming. Akhirnya Choliq hanya bisa pasrah, dan jenuh untuk memperingatkannya. Guru yang juga sebagai petugas pendamping desa ini mengatakan bahwa sebagian besar masyarakat Asinan sebenarnya merasa tidak nyaman, dengan para pelaku wama-wama ini. Pasalnya, perilaku yang hanya dilakukan oleh sedikit orang, namun seakan-akan semua penduduk desa ikut menyangganya.

Di Desa Krajanbogo, yang selama ini menjadi "pusat" administrasi wama-wama, tampaknya juga mulai kelihatan sepi. Sebagaimana dijelaskan sebelumnya, banyak para wama-wama yang "difasilitasi" oleh salah satu lembaga keagamaan di desa Krajanbogo ini. Para wama-wama ini biasanya mendapatkan surat permohonan sumbangan atau proposal pembangunan lembaga keagaman yang dibuat oleh panitia di Krajanbogo ini. Para wama-wama cukup hanya setor beberapa rupiah, yang jumlahnya variatif sesuai dengan kesepakatan, sebagaimana dijelaskan di atas.

Pernah suatu ketika, penulis mendapati seorang pelaku peminta sedekah yang sedang melaksanakan aktifitasnya di rumah penulis. Seorang perempuan berusia sekitar 40 tahunan, dengan berpakaian muslimah dan jilbab membawa kotak amal yang digembok.
Kami berbincang cukup lama dengan perempuan ini. Kebetulan pada saat itu bulan Ramadhan, siang hari saat cuaca sangat panas, sehingga sambil beristirahat.

Perempuan ini mengaku sebagai seorang ibu dari seorang santri yang mondok di salah satu pondok di Krajanbogo. Dengan dibekali kartu identitas, yang ketika saya cek nama, foto di identitas tersebut berbeda dengan foto aslinya. Surat identitas tersebut berukuran kertas A4 berisi keterangan bahwa pemilik surat ini sah sebagai panitia pembangunan yang bertugas mencari sumbangan. Surat keterangan identitas tersebut dilaminating plastik, kiranya untuk menghindari kerusakan dan menjaga keawetan. Ketika saya tanya, mengapa fotonya tidak sama, perempuan tersebut lalu menceritakan ikhwal tugas mencari sumbangan dengan kotak amal tersebut.

Menurut penuturannya, baru pertama kali melakukan aktifitas mencari sumbangan ini. Hal ini dilakukan karena anaknya sedang mondok di pesantren, dan mondoknya tersebut tidak bayar alias gratis. Sebagai kompensasi, maka orang tua mendapat tugas untuk mencari sumbangan, dengan dilengkapi kotak amal dan surat keterangan identitas tersebut. Karena baru pertama kali, maka sebenarnya terasa malas dan terpaksa, di samping itu juga ada rasa malu. Bahkan sebelumnya diceritakan sempat ditolak dan digertak ketika akan masuk ke pekarangan rumah salah satu warga.

Nah, untuk modus proposal dan kotak amal ini akhir-akhir ini sudah mulai jarang terlihat. Saya tidak tahu, apakah karena ada kasus terhadap para wama-wama ini, atau karena penghasilan yang menurun, mengingat warga atau masyarakat saat ini juga semakin cerdas, di sampaing saat ini mereka juga waspada terhadap penipuan dan pencurian yang berkedok tamu. Yang paling sering penulis jumpai adalah pasukan anak remaja yang menjajakan kalender dari salah satu lembaga keagamaan.

Ketika penulis mengunjungi lokasi yayasan atau lembaga yang tertera dalam berbagai surat dan proposal wama-wama di Krajanbogo, memang tampaknya lembaga tersebut terlihat sepi aktifitas. Ada pondok pesantren yang masih terlihat aktifitas santri, sebuah Masjid dan Madrasah Tsanawiyah. 
Untuk Madrasah Tsanawiyah ini terlihat sepi, tidak ada aktifitas pendidikan. Ketika saya tanyakan, Madrasah ini sudah tidak beroperasi lagi. Hal ini berbeda ketika penulis mengunjungi pada tahun 2011.

\section{Dari Proposal ke Kalender}

Sebagaimana telah dijelaskan sebelumnya bahwa beberapa praktik wama-wama yang sebelumnya banyak menggunakan surat atau proposal ini mulai banyak berkurang. Sebagian masyarakat sudah merasa curiga dengan praktik ini, yang sangat tipis perbedaannya dengan praktik mengemis berbalut agama. Beberapa masyarakat sudah "jenuh" dengan praktik wama-wama yang menggunakan modus surat atau proposal ini. Sebagaimana yang pernah disampaikan seorang informan yang sering didatangi para penyebar proposal ini. Menurutnya Ibu Siti, salah satu warga Dukuh Kedung Banteng yang pernah didatangi para wama-wama ini mengatakan tidak percaya sepenuhnya kalau uang hasil sedekah atau infaq yang dikumpulkan akan digunakan untuk kepentingan lembaga keagamaan. Menurutnya, mereka hanya menggunakan lembaga agama untuk mendukung pekerjaan mencari sedekah.

Hasil pengamatan para tetangga saya ketika didatangi para pencari sedekah ini menguatkan kecenderungan ini. Kebanyakan para warga yang didatangi terlihat tidak mempersilahkan masuk para tamunya. Mereka langsung memberikan uang ala kadarnya, seperti kalau mereka menghadapi para pengemis. Meskipun terlihat para wamawama ini mencoba meyakinkan tuan rumah maksud dan tujuan mereka. Hal ini kiranya tidak berlebihan, mengingat praktik seperti ini sering kali terjadi di kampung ini. Letak geografis yang persis di pinggir jalan "utama" menjadikan desa atau kampung ini sering disinggahi para pengemis, pengamen, sales, termasuk para pencari sedekah atau wama-wama. Sehingga bisa dikatakan praktik wama-wama dengan modus proposal ini sudah mulai berkurang. Jikalau masih ada, biasanya dilakukan oleh ibu-ibu.

Kecenderungan ini yang oleh beberapa wama-wama melahirkan modus baru yang lebih elegan, yakni dengan menjual kalender. Dengan menjual kalender, maka mereka akan tampak berbeda dengan pengemis. Dengan menjual kalender pula, mereka lebih percaya diri untuk melakukan aksinya, karena memang lebih elegan.

Seperti yang dilakukan oleh pengurus Pondok Pesantren Sulamul Huda di Dukuh Boyolangu, Desa Tlogoboyo Kecamatan Bonang Kabupaten Demak. Pihak pengurus menggunakan media kalender dalam rangka mendapatkan infaq untuk lembaganya. Mereka menjual kalender melalui anak remaja yang dikoordinir. Menurut penuturan Toha warga desa Tlogoboyo, praktik penjualan kalender dikoordinir oleh pengurus dengan merekrut para santri dan remaja sekitar. Mereka biasanya memberangkatkan para "pasukannya" ini mulai selepas ashar. Mereka difasilitasi armada berupa mobil minibus. Mobil-mobil ini akan mengantarkan ke daerah-daerah yang sudah ditentukan. Menurut penuturan remaja yang pernah melakukan praktik ini, mereka di antar ke sebuah lokasi, kemudian di sebar untuk menuju ke rumah-rumah. Biasanya, mobil akan menunggu di tempat yang ditentukan.

Pada awal November (2018), kebetulan peneliti didatangi salah seorang remaja yang menjual kalender ini. Dengan pakaian ala santri, baju koko putih, memakai sarung dan peci putih, Ahmad (bukan nama sebenarnya) mendatangi rumah-rumah di Dukuh. Ketika saya tanya, apa maksud dan tujuannya, dengan kalimat terbata-bata remaja tersebut menjelaskan kalau dia menawarkan kalender pondok. Remaja yang mengaku santri di pondok Sulamul Huda ini membawa dua puluh eksemplar kalender. Kalender tersebut terdiri dari tiga halaman, setiap halaman mencantumkan empat bulan, dengan foto header di atas dan beberapa foto-foto di samping sebelah kiri. Pada halaman pertama, foto-foto tersebut semuanya menampilkan gambar proses pembangunan gedung pondok. Ada kutipan ayat dari surat Al-Fatir ayat 29 , tertulis ayat dalam huruf arab beserta artinya: "Dan menafkahkan sebagian dari rezeki yang kami anugerahkan kepada mereka dengan diam-diam dan terangterangan, mereka itu mengharapkan perniagaan yang tidak akan merugi". Sebuah ayat yang tepat untuk memotivasi umat Muslim yang didatangi penjual kalender. Kalender tahun 2019 ini pada bagian kanan atas, tepat di bawah tulisan lembaga pendidikan "TPQ-Madin-SMP Islam" 
dengan nama thoriqoh dan pengasuhnya ini tertera, tarif kalender: Infaq Rp 20.000.

Jadi kalender ini dijual dengan tarif $\mathrm{Rp}$ 20.000 per eksemplar. Menurut penuturan Ahmad, setiap penjualan 1 kalender, dirinya mendapatkan semacam "bonus" Rp 5.000 Bisa dibayangkan setiap kali melakukan praktik ini, jikalau semua kalender habis terjual, Ahmad bisa mengantongi uang $\mathrm{Rp}$ 100.000. Hal ini belum beberapa "infaq" sukarela yang diberikan warga ketika tidak membeli. Menurutnya banyak warga yang ketika tidak minat untuk membeli, biasanya akan memberikan infaq secara sukarela. Dan hal ini menjadi penghasilan tambahan bagi para pasukan penjual kalender ini.

Ketika saya memperhatikan baju koko dengan dua saku di sebelah dada, kelihatan uang yang "mondol-mondol" dari kedua saku. Beberapa tampak uang pecahan $\mathrm{Rp}$ 5.000 dan Rp 2.000. Bisa jadi uang "receh" ini adalah hasil infaq yang diberikan oleh para warga yang tidak membeli kalender. Beberapa alasan mengapa warga tidak membeli biasanya karena sudah pernah membeli kalender yang sama. Hal ini karena memang kampung kami beberapa kali dikunjungi penjual kalender "yang sama", sehingga beberapa warga memang sudah memiliki kalender tersebut. Disamping karena alasan tidak memiliki uang "lebih" untuk membeli kalender.

\section{Kesimpulan}

Secara umum, motivasi perilaku wamawama ini adalah motivasi ekonomi dan motivasi agama. Motivasi ekonomi adalah faktor internal yang mendorong melakukan kegiatan mencari sedekah karena alasan ekonomi, untuk mendapatkan uang, pekerjaan dan kekayaan. Sedangkan motivasi agama mengindikasikan bahwa mereka mencari sedekah itu karena bagian dari perjuangan untuk lembaga keagamaan. Beberapa hasil mencari sedekah memang dipergunakan untuk keperluan membangun fisik lembaga keagamaan, mulai masjid, madrasah atau pondok pesantren.

Bentuk-bentuk perilaku pencari sedekah yang masih digunakan yaitu: menggunakan kotak amal, menggunakan surat atau proposal dan menjual kalender. Namun ada pergeseran yang signifikan bentuk perilaku pencari sedekah ini, yakni saat ini beberapa modus sudah beralih ke pola menjual kalender. Pola penjualan kalender dianggap lebih praktis dan elegan, serta tidak terkesan ada pola penipuan. Namun hal ini menjadi model keberagamaan baru, yakni cenderung masuk pada pola kapitalisasi agama.

Implikasi penelitian ini adalah memberi sebuah perspektif kepada masyarakat, bahwa penjualan kalender yang selama ini beredar di masyarakat, tidak murni merupakan kegiatan keagamaan. Masyarakat tidak perlu sungkan jika tidak membeli kalender atau memberi sedekah kepada para wama-wama ini.

\section{Daftar Pustaka}

Badudu, Y., \& Zain, S. M. (1994). Kamus umum Bahasa Indonesia. Pustaka Sinar Harapan.

Creswell, J. W. (1994). Research design: Qualitative \& quantitative approaches. Sage Publications.

Damayanti, F., Arsal, T., \& Sulaha, A. S. (2016). Kondisi Sosial Ekonomi Pengemis Dalam Perspektif Teori Dramaturgi (Studi Kasus Di Desa Pageralang, Kecamatan Kemranjen, Kabupaten Banyumas). Solidarity: Journal of Education, Society and Culture, 5(2), 143-154.

Hardiyantina, R., \& Sukardi, S. (2016). Studi Etnografi Perilaku Pengemis Masyarakat Desa Pragaan Daya Kabupaten Sumenep. Publisia: Jurnal Ilmu Administrasi Publik, 1(1). https://doi.org/10.26905/pjiap.v1i1.428

Kamus besar bahasa Indonesia. (2017). Badan Pengembangan dan Pembinaan Bahasa, Kementerian Pendidikan dan Kebudayaan.

M. Ali Humaidy. (2003). Pergeseran Budaya Mengemis di Masyarakat Desa Pragaan Daya Sumenep Madura. Masdura: STAIN Pamekasan.

Poerwadarminta, W. J. S. (1984). Kamus umum bahasa Indonesia. Balai Pustaka.

Praiwiroatmodjo, S. (1981). Bausastra JawaIndonesia: Abjad A - Ny. Gunung Agung.

Purwadi. (2003). Kamus Jawa-Indonesia. Pustaka Widyatama.

Saiful Umam. (2010, Agustus 4). Ngemis: Bermula dari Santri. Diambil 18 Juli 2019, dari Rmol.id website: https://rmol.id/read/2010/08/04/296/

Saleh, K., Riyanto, R., \& Mustaqim, M. (2014). Tradisi Mengemis: Pergulatan antara 
Ekonomi dan Agama: Studi Perilaku Mengemis Masyarakat di Demak. JURNAL PENELITIAN, 8(1), 23-44. https://doi.org/10.21043/jupe.v8i1.1339

Sugiyono. (2008). Metode penelitian pendidikan: (Pendekatan kuantitatif, kualitatif dan $R$ \& D). Alfabeta.

Suparlan, P. (1983). Kemiskinan di Perkotaan. Jakarta: Yayasan Obor.

Suparlan, P. (1986). Gelandangan Pandangan Ilmu Sosial. Jakarta: LP3ES.

Supraptingsih, U. (2012). Tradisi Mengemis di Tempat Wisata Religi. KARSA: Jurnal Sosial dan Budaya Keislaman, 18(2), 172-181.

Supraptiningsih, U. (2016). Karakteristik Pengemis Perempuan Di Kecamatan Tlanakan Kabupaten Pamekasan. NUANSA: Jurnal Penelitian Ilmu Sosial dan Keagamaan Islam, 13(2), 357-382. https://doi.org/10.19105/nuansa.v13i2.11 04

Syam, D. N. (2005). Islam Pesisir. Lkis Pelangi Aksara. www.depok.go.id. (2013). Larangan Memberikan Uang pada Pengamen dan Pengemis. Diambil 18 Juli 2019, dari Portal Resmi Pemerintah Kota Depok website: https://www.depok.go.id/03/12/2013/huk um-kota-depok/larangan-memberikanuang-pada-pengamen-dan-pengemis

www.pojokjabar.com. (2017, Maret 11). Di Kota Bandung Beri Uang ke Pengemis dan Anak Jalanan Bisa Disanksi. Diambil 18 Juli 2019, dari Pojok Jabar website: https://jabar.pojoksatu.id/bandung/2017/ 03/11/di-kota-bandung-beri-uang-kepengemis-dan-anak-jalanan-bisadisanksi/

Yatim, Y., \& Juliardi, B. (2016). Studi Gender: Jaringan Sosial Pengemis Anak Perempuan Di Kota Bukittinggi. Kafa`ah: Journal of Gender Studies, 6(2), 201-214-214. https://doi.org/10.15548/jk.v6i2.139 